Teologia i Moralność, volumen 12(2017), numer 2(22)

doi: 10.14746/tim.2017.22.2.16

\author{
REV. PAUL F. DELADURANTAYE \\ Diocesan Secretary for Religious Education \\ and the Sacred Liturgy \\ Diocese of Arlington, Virginia USA
}

\title{
Restoring the Image: the Confessor and the Challenge of Pornography
}

\section{Introduction}

On October 11, 2011, the presbyterate of the Diocese of Arlington, Virginia (USA) gathered for a presentation on the challenges presented to priestly and pastoral ministry posed by a sexualized culture. A good portion of the presentation and of the question-and-answer session which followed was devoted to the impact of pornography upon the men (and increasingly women) who become involved with it, especially as consumers, and how priests, specifically as confessors, might be able to aid penitents confessing such a sin.

Due to the nature of the sacrament of Penance, which involves, among other elements, the private confession of one's sins and the inviolable seal of confession, ${ }^{1}$ practically no formal studies have been published in regard to the frequency of penitents who confess an involvement with pornography. Anecdotal evidence, however, suggests that members of the faithful are increasingly caught up in the consumption of pornographic materials and are confessing

\footnotetext{
${ }^{1}$ On the private confession of one's sins, see, for example, the Council of Trent, "Doctrine on the Sacrament of Penance," Session 14 (November 25, 1551) in Heinrich Denzinger, Enchiridion Symbolorum, Definitionum et Declarationum de Rebus Fidei et Morum, $43^{\text {rd }}$ edition, San Francisco 2012, nos. 1683 and 1706. On the inviolability of the seal of confession, see the Catechism of the Catholic Church, Vatican City State 1997, no. 1467 and the Code of Canon Law, Vatican City State 1983, canons $983 \S 1$ and $1388 \S 1$.
} 
such a sin more frequently. ${ }^{2}$ In recent years, two bishops in the United States have directly addressed the spread of pornography and its harmful effects. ${ }^{3}$ Addressing confessors directly, Bishop Robert W. Finn of the Diocese of Kansas City-Saint Joseph wrote, "As ministers of the Sacrament of Penance, priests are in a unique position to help people who struggle with this problem and to offer them hope and healing. Study and reflect on this weighty pastoral challenge so that you may better serve those who seek your help."4 It is hoped that this article will be of aid to confessors by providing, first, an outline of the scope and impact of the problem of pornography and second, some observations regarding the ministry of the confessor who is called to offer the penitent the healing grace of God in the sacrament of Penance so that the divine image, originally bestowed on every human being at creation (cf. Gen. 1:26-27), may be restored, and that the forgiven sinner might rediscover his or her inner freedom so as to embrace and live the truth and beauty of God's plan for human sexuality and authentic love.

\section{Understanding the Current Threat of Pornography}

Porn is a problem. It's a personal problem for many and a cultural problem for all. You may think you have not been affected by porn, but you have because it's embedded in the surrounding culture. The staggering size of the pornography industry, its influence upon the media and the acceleration of technology, paired with the accessibility, anonymity, and affordability of porn all contribute to its increasing impact upon the culture. ${ }^{5}$

${ }^{2}$ See, for instance, Most Reverend Paul S. Loverde, Bought with a Price: Every Man's Duty to Protect Himself and His Family from a Pornographic Culture, $2^{\text {nd }}$ edition, Arlington 2014, p. 16: "I know of this plague from my brother priests who routinely confront it in the confessional; from counselors who treat it through our various Catholic social service agencies; from Catholic school teachers, youth ministers, and religious education teachers who confront its effects in the lives of our youth; from parents who speak of the challenge of raising children with modesty in our culture; and from my involvement in the Religious Alliance Against Pornography, an interfaith coalition of religious leaders."

${ }^{3}$ The two bishops are the Most Reverend Paul S. Loverde, Bishop of Arlington, Virginia, who issued a pastoral letter (Bought with a Price, see note 3 above) in 2006 and a revised version in 2014; and the Most Reverend Robert W. Finn, Bishop of Kansas City-Saint Joseph, Missouri, who issued a pastoral letter (Blessed Are the Pure in Heart) in 2007.

${ }^{4}$ Most Reverend Robert W. Finn, Blessed Are the Pure in Heart: A Pastoral Letter on the Dignity of the Human Person and the Dangers of Pornography, Kansas City-Saint Joseph 2007, chapter 3.

${ }^{5}$ B.J. Stockman, 7 Negative Effects of Porn, available at: http://theresurgence.com/2011/11/ 19/7-negative-effects-of-porn/ [accessed August 22, 2014, 11:03 GMT]. 
No person living in our culture can totally separate himself or herself from the scourge of pornography. All are affected to a greater or lesser extent, even those who do not directly participate in the use of pornography. ${ }^{6}$

Data gathered from various sources support the above-cited affirmations. For example, with reference only to an adult population in the United States, ${ }^{7}$ 10 percent of adults surveyed admitted to an internet sexual addiction; 28 percent of these adults are women. ${ }^{8}$ Forty million adults in the United States regularly visit internet pornography websites, ${ }^{9}$ and numerous adults do so at work (20 percent of men and 13 percent of women). ${ }^{10}$ Sixty-seven percent of young adult men (aged 18-26) believe that viewing pornography is acceptable, while 49 percent of young adult women (also aged 18-26) share the same belief. ${ }^{11}$

More generally, 42.7 percent of internet users view pornography, ${ }^{12}$ while fully 25 percent of daily search engine requests are requests for pornographic material (this amounts to 68 million search requests per day). ${ }^{13}$ Current estimates are that 20 billion dollars are spent annually on sales and rentals of adult videos, while the purchase of pornographic magazines accounts for approximately 7.5 billion dollars. ${ }^{14}$ According to research done in 2008 by Kirk

${ }^{6}$ Loverde, Bought with a Price, p. 23.

${ }^{7}$ Children and youth also constitute a significant population which either consumes, or is affected by, internet pornography. Access to the internet as well as the use of social media by pre-teens and teenagers provides an opportunity not only for viewing pornography but also for "sexting" (sending or posting nude or semi-nude pictures and/or videos of themselves) and engaging in sexually suggestive text messages or emails in order to be "fun or flirtatious." See Archdiocese of Kansas City, Pornography Statistics, "Archdiocese of Omaha Anti-Pornography Task Force," 2012, available at: http://www.archomaha.org/pastoral/se/pfd/PornStats.pdf/ [accessed August 22, 2014, 11:05 GMT]; Finn, Blessed Are the Pure in Heart, chapter 2. In addition, incidents of sexual exploitation of children have risen from 4,573 in 1998 to 112,083 in 2004, according to the National Center for Missing and Exploited Children, Reports of Child Exploitation Up, "USA Today Snapshots," February 17, 2005, available at http://pqasb.pqarchiver.com/USAToday/doc/408935815. html [accessed September 8, 2014, 10:16 GMT]. Between 2004 and 2008, according to research done by the Crimes Against Children Research Center, over the course of one year 1 in 25 youth received an online sexual solicitation where the solicitor subsequently attempted to make offline contact. See Crimes Against Children Research Center, Internet Safety Education for Teens: Getting It Right, University of New Hampshire Horton Social Science Center, 2009, available at: http:// www.unh.edu/ccrc/internet-crimes/safety_ed.html/ [accessed August 22, 2014, 11:07 GMT].

${ }^{8}$ Archdiocese of Kansas City, Pornography Statistics.

9 United Families International, 14 Shocking Pornography Statistics, "United Families International" 2010, available at: http://unitedfamiliesinternational.wordpress.com/2010/06/02/14shocking-pornography-statistics/ [accessed August 22, 2014, 11:15 GMT].

${ }^{10}$ Ibid. See also Archdiocese of Kansas City, Pornography Statistics.

${ }^{11}$ Archdiocese of Kansas City, Pornography Statistics.

12 Family Safe Media, Pornography and Divorce, June 2012, available at: http://www. divorcewizards.com/Divorce-Statistics-Pornography.html/ [accessed August 22, 2014, 11:23 GMT].

${ }^{13}$ United Families International, 14 Shocking Pornography Statistics.

${ }^{14}$ Cited in Finn, Blessed Are the Pure in Heart, chapter 2. 
Doran, an assistant professor of economics at the University of Notre Dame, 14 percent of the online population in the United States visit adult websites and spend an average of 6.5 minutes per visit. Eighty to ninety percent (approximately 32-37 million) of this population only access free pornographic material, while the remaining 3 million Americans who pay for internet pornography pay an average of 61 dollars per month; this generates between 2.5 to 2.8 billion dollars in annual revenues for the pornography industry in the United States. The entire worldwide industry is worth approximately 4.9 billion dollars per year. ${ }^{15}$

Most disquieting are the data concerning Christians generally and clergy specifically. Although the various published surveys, polls and studies do not tend to distinguish Catholics from other members of Christian ecclesial communities, nor between Catholic priests and other Christian ministers or pastors, nonetheless what is reported gives cause for concern. For instance, 29 percent of "born-again" adults in the United States believe it is morally acceptable to view movies that contain explicit sexual behavior, ${ }^{16}$ while 33 percent of clergy admitted to having visited a sexually explicit website. Additionally, 53 percent had visited such sites "a few times" over the course of a year, and 18 percent visit sexually explicit sites between a couple of times a month and more than once a week. ${ }^{17}$ Moreover, 57 percent of pastors say that addiction to pornography is the most damaging issue to their congregations, and almost 9 in 10 pastors report counseling a layperson on sexual issues once a year or more.

While researchers and social scientists can, at times, argue over the methodology and results of surveys and studies on any given topic, it seems clear, however, that the scope of the problem of pornography is not small, and that, based simply on percentages alone, priest confessors are ministering - and will likely continue to minister - to a number of persons in their own congregations who struggle with pornography, whether it be with a more or less strong addiction or with an habitual or occasional involvement. Moreover, behind the numbers and statistics that surveys and studies generate, there are real persons whose lives are harmed, and whose salvation is put in jeopardy. As Bishop Loverde has observed, pornography is not a victimless activity: thousands of men and women have been lured into the pornography industry by the promise of easy money only to be exploited for the profit of those who prey on vulnerable individuals. Then, too, "Those who view pornographic materials cannot

${ }^{15}$ Kirk Doran, The Economics of Pornography, presented at a symposium on "The Social Costs of Pornography," Princeton, New Jersey, December 11-13, 2008, available at: http://www.winst.org/ family_marriage_and_democracy/social_costs_of_pornography/Doran-Economics-Pornography. pdf/ [accessed August 22, 2014, 12:05 GMT].

${ }^{16}$ Archdiocese of Kansas City, Pornography Statistics.

${ }^{17}$ Ibid. 
separate themselves from the moral responsibility associated with the victimization and degradation of the men, women and children these materials depict. And the viewers themselves are degraded." 18

\section{Understanding the Harm of Pornography}

The Catechism of the Catholic Church notes a three-fold harm presented by pornography:

It offends against chastity because it perverts the conjugal act, the intimate giving of spouses to each other. It does grave injury to the dignity of its participants (actors, vendors, the public), since each one becomes an object of base pleasure and illicit profit for others. It immerses all who are involved in the illusion of a fantasy world. It is a grave offense. Civil authorities should prevent the production and distribution of pornographic materials. ${ }^{19}$

Often, penitents who confess an involvement with pornography will understand that they have violated a commandment - a prohibition from God against unchastity, impurity and lust--and are sorry for having done so. Yet, as the late Dominican moral theologian, Servais Pinckaers, has written, "Catholic moral teaching is not a mere code of prescriptions and prohibitions... Rather, Catholic morality is a response to the aspirations of the human heart for truth and goodness... It seeks to educate for growth. This is its true mission." ${ }^{20} \mathrm{Sin}$ clearly involves a transgression against a law that has its ultimate source in God Himself. At the same time, though, sin at its root is a failure in genuine love for God and neighbor. As Saint Augustine remarked, sin is "love of oneself even to contempt of God." ${ }^{21}$ This prideful self-exaltation exceeds the boundaries of right reason and therefore does damage to the imago Dei which stands at the foundation of human dignity. Because sin distorts and obscures the godly image in which each person is made, there is a need to restore the truth of that image and therefore the dignity of each person made in that image through the grace of the Sacrament of Penance. This is the confessor's principal role: to be "the sign and instrument of God's merciful love for the sinner" 22 so that the penitent can be "re-created," as it were, according to the divine im-

\footnotetext{
${ }^{18}$ Loverde, Bought with a Price, p. 27.

${ }^{19}$ Catechism of the Catholic Church, no. 2354.

${ }^{20}$ Servais Pinckaers, O.P., Morality: The Catholic View, trans. by Michael Sherwin, O.P., South Bend, Indiana 2001, p. 1.

${ }^{21}$ Saint Augustine, De civitate Dei 14, 28; PL 41, 436.

${ }^{22}$ Catechism of the Catholic Church, no. 1465.
} 
age. Moreover, when exercising his ministry, the confessor, by his advice and counsel, is in a position to help the penitent open his or her heart once more to that which is authentically true and good, and which ought to be presented to the penitent as being more attractive than the false images offered by pornography. In this sense, as the above quote from paragraph 2354 of the Catechism observes, the harm of pornography consists in much more than merely breaking a rule; it consists principally in a distorted view of human sexuality which offends against the virtues of chastity and justice - and such an offense occurs on both the personal and the social levels. ${ }^{23}$ Part of the task of the confessor, therefore, is to aid penitents in grasping the deeper harm done - to themselves and to others -by the use of pornography. This is especially necessary if a penitent has in some fashion adopted the false argument that pornography is essentially a victimless crime and is only confessing out of a sense of having violated a rule.

The first harm of pornography, as the Catechism of the Catholic Church expresses it, consists in the perversion of the conjugal act by reducing that act to a demeaning source of entertainment and even profit for others. Pornography turns the beauty of the human body and the mutual self-gift which lies at the heart of the conjugal act into a form of voyeuristic fixation on anonymous body parts. Persons who engage in pornography, whether as actors, producers or vendors, or who view pornography for the sake of obtaining venereal pleasure, participate in an objective falsification of the beauty of that intimate love proper to marriage. In this regard, the words of Pope Emeritus Benedict XVI, though written to address a somewhat different and more generally pervasive problem, provide commentary on the damage pornography causes:

Eros, reduced to pure "sex," has become a commodity, a mere "thing" to be bought and sold, or rather, man himself becomes a commodity. This is hardly man's great "yes" to the body. On the contrary, he now considers his body and his sexuality as the purely material part of himself, to be used and exploited at will. Nor does he see it as an arena for the exercise of his freedom, but as a mere object that he attempts, as he pleases, to make both enjoyable and harmless. Here we are actually dealing with a debasement of the human body; no longer is it integrated into our overall existential freedom; no longer is it a vital expression of our whole being, but it is more or less relegated to the purely biological sphere. ${ }^{24}$

${ }^{23}$ Bishop Loverde observes that pornography carries with it a further harm, namely, that it "represents a serious abuse of the means of communication, and in that regard, is a violation of the eighth commandment." See Bought with a Price, p. 20. Hence the Catechism calls upon civil authorities to "prevent the production and distribution of pornographic materials" (Catechism of the Catholic Church, no. 2354).

${ }^{24}$ Pope Benedict XVI, Encyclical Letter Deus Caritas Est, Vatican City State 2006, no. 5. 
This first harm of pornography (the perversion of the intimate goodness and beauty of the conjugal act) very often leads to further offenses against the virtue of chastity. Most confessors who have heard penitents confess an involvement with pornographic materials are not terribly surprised when other unchaste thoughts or actions stemming from the use of pornography are also revealed in the confessional. For example, viewing pornographic images fuels interior acts of lust (e.g. thoughts, desires and fantasies) which then frequently result in masturbation. Involvement with pornography can also cause a person to seek other disordered forms of sexual gratification and in some instances engage in alcohol and drug abuse. ${ }^{25}$ Above all, pornography is a violation of chastity because pornography replaces love with use. Since it "immerses all who are involved in the illusion of a fantasy world," 26 pornography violates the truth about persons, who become little more than interchangeable objects, available for exploitation. Such an attitude runs directly counter to what Pope Saint John Paul II had expressed as the "personalistic norm":

This norm, in its negative aspect, states that the person is the kind of good which does not admit of use and cannot be treated as an object of use and as such the means to an end. In its positive form the personalistic norm confirms this: the person is a good towards which the only proper and adequate attitude is love. ${ }^{27}$

According to the late pope, to "use another" can mean, on one hand, that one person makes a second person a means to an end that the former has in mind, and, on the other, to "use another" can also mean that a person becomes merely a source of pleasure or gratification for someone else - in this case sexual pleasure. ${ }^{28}$ On the other hand, to "love another" means to affirm the value of that other, precisely as a whole person, and not to limit oneself solely to partial values or particular qualities inherent in a person - in this case, again, the

${ }^{25}$ See Archdiocese of Kansas City, Pornography Statistics. The consequences, demonstrated by contemporary research, of a person's involvement with pornography support in an empirical way the teaching of Saint Thomas Aquinas on the vice of lust. Saint Thomas observes, "When the lower powers [of the soul] are strongly moved towards their objects, the result is that the higher powers are hindered and disordered in their acts." The Angelic Doctor goes on to elaborate how the higher powers (namely, reason and will) are disordered: with regard to a person's reason, lust produces blindness of mind, rashness, thoughtlessness and inconstancy. With regard to the will, lust produces self-love, hatred of God, love of this world and abhorrence or despair of a future world. See Saint Thomas Aquinas, Summa Theologiae II-II, q. 153, a. 5. Many confessors, on the basis on their experience, can verify Saint Thomas' observations, as penitents demonstrate, through the confession of sins of lust, that what ought to be the good habits of right reason and right willing are impeded, sometimes severely, by exposure to pornographic materials.

${ }^{26}$ Catechism of the Catholic Church, no. 2354.

${ }^{27}$ Karol Wojtyla, Love and Responsibility, trans. by H. T. Willetts, New York 1981, p. 41.

${ }^{28}$ Ibid., pp. 25-34. 
sexual value associated with being male or female. Since pornographic imagery is explicitly intended to stimulate an erotic reaction in those who view it by removing sexual activity from authentic conjugal intimacy and love, the one exposed to pornography is literally "de-personalized," with his or her moral sense in danger of being de-sensitized to the good of the whole person - both the other and also oneself. In this vein, Bishop Loverde writes,

It is a mistaken notion that the singular effect of sinful moral choices is the harm these choices cause to others. Certainly, the immediate effect of choosing to participate in pornographic viewing is the spiritual and emotional violence committed against those whose images are viewed. Yet, the personal and existential effect on the one choosing to view pornographic images lies at the heart of these sinful actions... When one chooses to view pornography, even if at first reluctantly, one becomes the kind of person who is willing to use others as mere objects of pleasure, disregarding their inherent dignity as a man or woman created in God's image. As the habit of pornography becomes more fixed, the characteristics of a person who debases and objectifies others and wills violence against their dignity become more pronounced. ${ }^{29}$

As those engaged in the cura animarum, especially in the confessional, priests are called upon to help penitents realize the spiritually, emotionally and in some cases physically self-destructive nature of pornography. As noted previously, more is at stake than the mere breaking of a rule. Rather, one's ability to "see" the good, the true and the beautiful becomes warped, and the more one becomes mired in vice and the search for venereal pleasure, the more one risks losing his or her "taste" for the supernatural. The confessor should, then, with his words and most importantly with his prayer, be ready to aid a penitent in overcoming the inversion of goods and values that comes with involvement in pornography. He should point out how, in a manner analogous to the sin of masturbation, pornography turns a person in on himself or herself, leading to a preoccupation with self-gratification that ultimately cannot but weaken a person's interpersonal skills and relationships, stunt one's emotional growth, and in certain instances cause real damage to personal, familial and social life.

The damage to others that can be caused by involvement in pornography leads to a third harm: pornography offends against the virtue of justice. "Justice is the moral virtue that consists in the constant and firm will to give their due to God and neighbor." ${ }^{30}$ What is due to one's neighbor is, most fundamentally, the recognition of and respect for his or her inherent dignity (and in exercising

${ }^{29}$ Loverde, Bought with a Price, pp. 27-28.

${ }^{30}$ Catechism of the Catholic Church, no. 1807; see also Saint Thomas Aquinas, Summa Theologiae II-II, q. 58, a.1. 
such respect, one is also acting justly towards God, the source of that dignity). It has been noted above how pornography offends against the dignity of the person, doing a grave injustice to oneself and to others. Further injustices are caused when those who are caught in the vice of pornography are married and have children. Priests, both inside and outside of the confessional, as well as other pastoral counselors, know well how grave a threat pornography poses to the intimate bond of marriage and how many families have suffered due to its effects. When a spouse turns to pornography, at times out of curiosity, more often out of a distorted desire for intimacy, that spouse turns against and in some measure rejects his or her commitment to the other spouse and to the larger family. Such an injustice committed against one's spouse is, at the same time, an injustice committed against one's own vocation: one seeks emotional or sexual satisfaction outside of, or even in place of, the marital communio personarum which "demand[s] total fidelity from the spouses and require[s] an unbreakable unity between them.." ${ }^{\prime 31}$ Furthermore,

Once given over to this vice, the family member makes great efforts to keep this betrayal secret. Ultimately, however, it is vain to expect that a secret that distorts the core of human sexuality can fully remain a secret from those to whom we have pledged our love and our lives. The betrayal, even if not made completely known, will communicate itself through changes in the character of the betrayer. In the isolation and alienation of the person, the other members of the family feel the inevitable consequences of the alienation of intimacy inherent in the secret of pornography.

The first to feel the violence of pornographic use is the spouse. If pornography is a sin against the human dignity of those whose images are used, how much more so is it a sin against the human dignity of the one who was promised the exclusivity of affection? Even if tolerated by the spouse, how can one possibly not feel rejection and betrayal when one's committed partner turns to illusion and fleeting happiness in pornographic images? ${ }^{32}$

Involvement with pornography carries with it a further injustice if there are children in the home. Instead of sharing in and experiencing the mutually self-donative love of their parents, children find themselves faced with tension, betrayal and selfishness which, if not addressed and healed, can lead them to believe that true love, a sacrificial and self-giving love, is an illusion.

${ }^{31}$ Second Vatican Council, Gaudium et Spes, no. 48, in Austin Flannery, ed., Vatican Council II: The Conciliar and Post-Conciliar Documents, Northport, New York, 1975, p. 950. See also Pope Pius XI, Encyclical Letter Casti Connubii, “Acta Apostolicae Sedis” 22 (1930), pp. 546-547.

${ }^{32}$ Loverde, Bought with a Price, pp. 30-31. 
Moreover, children are often exposed to, or at least encounter - even if unwillingly - the very material that has caused damage to their family and thus can experience a grave obstacle to their authentic human development. "Instead of learning and experiencing the nobility of the human person created in the image and likeness of God, they experience the degradation of the human person reduced to a commodity, to an object." 33 Additionally, children exposed to pornography, even accidentally, risk becoming consumers themselves as they grow older. ${ }^{34}$

\section{The Ministry of the Confessor}

The Sacrament of Penance holds a special place in the sacramental life of the Church. In his 1984 Apostolic Exhortation Reconciliatio et Paenitentia, Pope Saint John Paul II has pointed to this sacrament as a principal locus where through the working of the Holy Spirit the human person encounters the reconciliation brought about by the death of Jesus Christ. ${ }^{35}$ The power of Christ's Passion mediated in the sacrament turns the penitent person back to God, with a purpose of amendment, as a son or daughter turn toward their father. It is precisely in this aspect of divine forgiveness that the Church especially discerns the healing or medicinal character of the Sacrament of Penance. God, in short, desires more to draw His errant children back to loving union with Himself than to punish them according to any canon of vindictive justice. Thus the Catechism of the Catholic Church, citing the teaching of Pope Saint John Paul II, emphasizes the fruits of the sacrament: a restoration to God's grace, a true "spiritual resurrection," a strengthening in what is good, and a reconciliation with the Church, with others and with oneself. ${ }^{36}$ For a penitent who struggles with pornography, the Sacrament of Penance offers an infallible source of healing grace. Since the use of pornography (as is the

${ }^{33}$ Ibid., p. 31.

${ }^{34}$ It is generally accepted that the average age of a person's first exposure to internet pornography is 11 years old, and that the largest consumer of internet pornography is 12-17 yearolds. Eighty percent of 15-17 year-olds have had multiple exposures to hard-core pornography. See Archdiocese of Kansas City, Pornography Statistics. It should be noted that the data referenced here seem to concern primarily an intentional exposure on the part of a young person - that is, an active search for pornographic images; however, it would not be difficult to imagine a similar trajectory occurring in the life of an adolescent or pre-adolescent who, accidentally exposed to pornography at first, subsequently begins to engage more actively with it.

${ }^{35}$ Pope John Paul II, Apostolic Exhortation Reconciliatio et Paenitentia, Vatican City State 1984.

${ }^{36}$ See Catechism of the Catholic Church, nos. 1468-1469; cf. Pope John Paul II, Reconciliatio et Paenitentia, no. 31. 
case with any sin) alienates a person from others (including God and oneself), the Sacrament of Penance provides the normal means whereby the divine image in a sinful penitent is restored, the soul is cleansed of the false and warped image of intimate love presented by pornographic material, and the forgiven sinner is brought back into communion with God, by reason of which other reconciliations are made possible: "The forgiven penitent is reconciled with himself in his inmost being, where he regains his own true identity. He is reconciled with his brethren whom he has in some way attacked and wounded. He is reconciled with the Church." 37

It is precisely such forgiveness and reconciliation that a penitent who confesses the sin of pornography seeks. The confessor, therefore, by means of counsel given to the penitent, must help him or her see the real harm of pornography and how, beyond merely violating a commandment, pornography disfigures the imago Dei within every person.

Admittedly, most confessors will not be able to spend a great deal of time in dialogue with a penitent who confesses involvement with pornography. Therefore, a confessor should be prepared to offer some brief words of counsel that will aid a penitent in recognizing the damage pornography causes and strengthen his or her purpose of amendment. In this regard, it is not enough simply to point out the moral evil and objective grave sinfulness of pornography. Rather, a confessor ought to lead a penitent to a better and more fulfilling vision of the good. Vice must be replaced by virtue. The penitent must be helped to set aside the pornographic images that have distorted who the human person is and what human intimacy is called to be in favor of a purified vision of genuine love and self-giving. In this regard, a confessor becomes not only a minister of God's healing mercy but also an ambassador of the truth: the truth - in this case - about human sexuality and its goodness and beauty when it is exercised properly according to God's plan for human life and love.

Because the human person is set between God as both Origin and Goal, the moral theologian needs to point out the way that leads to God...An adequate presentation of Christian moral theology also requires that some account be given of what constitutes the proper steps along the way...sound moral theology always points to Christ. $^{38}$

If "confessor" is substituted for "moral theologian" and "confessional practice" for "moral theology," what Father Cessario writes is an apt description of how a confessor should deal with the challenge posed by pornography:

\footnotetext{
${ }^{37}$ Pope John Paul II, Reconciliatio et Paenitentia, no. 31.

${ }^{38}$ Romanus Cessario, O.P., Introduction to Moral Theology, Washington, D.C. 2001, pp. 5-6.
} 
to point out to a penitent the way that leads to God, how one progresses along this way, and ultimately to assist a penitent in placing his or her confidence in Christ Jesus who provides, for those willing to accept it, the strength and grace necessary to advance on the path of conversion - turning away from some disordered attachment and turning toward the mercy and love of God.

An important element in a confessor's indicating the path of conversion to a penitent is found on a very practical level, namely, guiding a penitent to adopt a real plan to avoid not only the sin of pornography itself but also the occasions giving rise to that sin. Confessors can help penitents examine their particular weaknesses in regard to their involvement with pornography and suggest concrete steps a penitent ought to take in order to defend himself or herself against this vice. Such steps would include: the avoidance of a secretive environment (e.g. locating a computer in an open area of a home rather than in a private room); being a good steward of one's time so as to reduce or eliminate a temptation to engage in viewing pornography; and, if the case warrants it, eliminating one's access to pornography (e.g. cancelling problematic cable or satellite television channels, installing filtering software on a personal computer, even ridding oneself of a computer, television or other media device altogether). On a more positive note, a confessor should guide a penitent to the formation of good habits: a commitment to daily prayer and a daily examination of conscience; frequent reception of Holy Communion which, provided one is not in a state of serious sin, can help a person remain in the friendship of God; the utilization of good spiritual reading; the use of sacramentals (e.g. keeping a religious medal, holy card or icon on or near the screen of one's computer or television can help a person be more aware of his or her commitment to live a new life in Christ); the practice of regular spiritual direction; and certainly the practice of the regular reception of the Sacrament of Penance, ideally with the same confessor. These classic spiritual practices help to build up a person's spiritual resources and strength, fortifying one's will to shun sin and the occasions of sin while intensifying one's commitment to Christ Jesus, the Way, the Truth and the Life (cf. Jn. 14:6).

On occasion, however, a confessor may encounter a case in which a penitent is suffering from an involvement with pornography that bears characteristics associated with a deep-seated compulsion, if not a real addiction. ${ }^{39}$ In such instances, it is useful to recall a distinction made by Saint Thomas Aquinas

39 The psychological and mental health literature offers conflicting interpretations as to the existence of an addiction in the strict sense to pornography. Some researchers do not hesitate to use the term "addiction," while others prefer to speak of "compulsion" or "obsession." It is not the intent of this article to enter into this disputed area, but merely to point out that confessors can and do deal with penitents who confess a "helplessness" or "powerlessness" with regard to their ability to cease involvement with pornography. 
between peccatum and culpa. "A "A peccatum, which should best be translated as a misstep, denotes a human action which lacks the appropriate reference to reason. The qualification supplied by right reason is absent. The culpa refers to a misstep that was willed." ${ }^{41}$ In light of this distinction, a penitent who confesses a compulsion to view pornography or a helplessness to resist such behavior has clearly entered upon an objective peccatum. Yet the question arises: Is the peccatum also a culpa? Here, the confessor must judge whether such behavior has occurred outside the scope of the penitent's free choice. In this latter case, the culpa may be limited or even non-existent. Nevertheless, the objective fact of the peccatum remains, and the confessor may need to advise a penitent that, in addition to the spiritual remedies mentioned above, he or she ought to seek appropriate counseling from a competent professional or to participate in a support group for those struggling with pornography. In this regard, priestconfessors (outside of the context of the Sacrament of Penance) might consult diocesan agencies such as Catholic Charities or a Family Life Office in order to become familiar with professional counselors whose expertise is rooted in a Christian anthropology and who would be able to assist those struggling with pornography from a truly Catholic (and not merely secular) perspective. Similarly, it would be to the advantage of priest-confessors to become aware of support groups that, even if not explicitly Catholic, are nonetheless based on a sound vision of the human person. ${ }^{42}$ It would be irresponsible for a confessor simply to excuse, treat lightly or overlook an objective moral wrong (peccatum) even though a particular penitent may not bear full moral culpability for actions that proceed from an inner compulsion or addiction. It would be equally irresponsible, however, if a confessor were to deny absolution unless a penitent guaranteed that his or her future behavior would be absolutely irreproachable. ${ }^{43}$

${ }^{40}$ Saint Thomas Aquinas, De Malo, trans. by John Oesterle, Notre Dame, Indiana 1995, q. 2, a. 2: ".....any privation whatever of form or of order or of due measure either in the subject or in the act, has the nature of evil. But any act lacking due order or form or measure is called a sin (peccatum)... But sin has the nature of fault (culpa) only from the fact that it is voluntary..."

${ }^{41}$ Wojciech Giertych, O.P., Free Will, Addiction, and Moral Culpability, "Addiction and Compulsive Behaviors: Proceedings from the 17 ${ }^{\text {th }}$ Workshop for Bishops," Boston 2000, p. 122.

${ }^{42}$ In the Diocese of Arlington, for example, counselors who work for Catholic Charities receive training on the elements of a Christian anthropology several times a year. Within the boundaries of the diocese (even though not officially connected with the diocese), the Institute for Psychological Sciences in Alexandria, Virginia and the Alpha-Omega Clinic in Fairfax, Virginia both operate on the basis of a Christian anthropology. With regard to support groups, Augustine's Brothers (www.augustinesbrothers.org) offers a Catholic foundation for men who need help and support in overcoming involvement with pornography, while Reclaim (www.reclaimsexualhealth.com) is a Catholic online resource rooted in Pope Saint John Paul II's "Theology of the Body." Sexaholics Anonymous (www.sa.org) provides information and a generally sound Twelve Step Christian spirituality for those struggling with sexual addiction.

${ }^{43}$ On this point, it is helpful to see the Pontifical Council for the Family's Vademecum for Confessors concerning Some Aspects of the Morality of Conjugal Life, Vatican City State 1997, 


\section{Conclusion}

Confessors today are faced with an increasing number of penitents who seek forgiveness for the sin of pornography. Some penitents enter the confessional genuinely ashamed of having fallen into this sin and resolved to amend their ways; others confess it out of a sense of duty ("I broke a commandment"); while still others may be on the point of despair ("I will never overcome this sin"). Some penitents have viewed or otherwise become involved with pornography on an occasional basis, while for others, the involvement (and the struggle) is much more severe, perhaps even life-long.

Though pornography poses a serious challenge to the Sacrament of Penance, priest-confessors are in a unique position to help people who struggle with this problem and to offer them hope and healing. The aim of a confessor, who acts as an instrument of the mercy of God, should be that of aiding in the restoration of the divine image within each penitent, so that, having been set free from the false images of intimacy and love held out by pornography, he or she can once again embrace and live the truth in freedom. The Sacrament of Penance remains a privileged moment of this work of "image-restoration," being both a sign and cause of that personal healing which consists "in restoring us to God's grace and joining us with him in an intimate friendship." 44

\section{SUMMARY}

Increasingly, many confessors are confronted with penitents who have become involved with pornography. This article provides some statistics illustrating the scope of pornography and then analyzes the harm that pornography causes, both to the dignity of the human person and in relation to the virtues of chastity and justice. The article invites confessors to help penitents understand that involvement with pornography is

nos. 5 and 11. Although the specific issue addressed in these paragraphs is that of contraception, what is stated in the Vademecum can apply equally well to the problem of pornography: "Frequent relapse into sins of contraception does not in itself constitute a motive for denying absolution" (no. 5) and "Sacramental absolution is not to be denied to those who, repentant after having gravely sinned against conjugal chastity, demonstrate the desire to strive to abstain from sinning again, notwithstanding relapses. In accordance with the approved doctrine and practice followed by the holy doctors and confessors with regard to habitual penitents, the confessor is to avoid demonstrating lack of trust either in the grace of God or in the dispositions of the penitent, by exacting humanly impossible absolute guarantees of an irreproachable future conduct" (no. 11).

${ }^{44}$ Catechism of the Catholic Church, no. 1468. 
more than simply breaking a commandment, but rather affects a penitent's capacity for self-giving and thus one's authentic emotional and spiritual growth. Confessors should guide penitents who struggle with this issue to cultivate the true vision of human love in place of the distorted image offered by pornographic material. The confessor should be prepared to turn a penitent's attention to effective spiritual remedies as well as in some cases suggesting a penitent seek professional assistance so that the authentic image of God may be restored and the penitent be helped to attain true freedom from the vice of pornography.

Keywords: confessor; harms of pornography; dignity of the person; spiritual remedies; addiction; professional counseling; imago Dei

\section{BIBLIOGRAPHY}

Aquinas, Thomas, De Malo, trans. by John Oesterle, Notre Dame, IN: University of Notre Dame Press, 1995. ISBN 0-268-03700-0.

Aquinas, Thomas, Summa Theologiae, trans. by the Fathers of the English Dominican Province, Westminster, MD: Christian Classics, 1981. ISBN 0-87061-063-5.

Archdiocese of Kansas City, Pornography Statistics [2012], available at:

$<$ http://www.archomaha.org/pastoral/se/pfd/PornStats.pdf/>

Augustine, De civitate Dei in J. P. Migne, Patrologia Latina, 41, 436.

Benedict XVI, Deus Caritas Est, Vatican City State: Libreria Editrice Vaticana, 2006. ISBN 0-81983106-9.

Catechism of the Catholic Church, Vatican City State: Libreria Editrice Vaticana, 1997. ISBN 1-57455-109-4.

Cessario, R., O.P., Introduction to Moral Theology, Washington, D.C.: The Catholic University of America Press, 2001. ISBN 0-8132-1070-4.

Code of Canon Law, Vatican City State: Libreria Editrice Vaticana, 1983. ISBN 0-943616-79-4.

Crimes Against Children Research Center, Internet Safety Education for Teens: Getting It Right, [2009], available at: $<$ http://www.unh.edu/ccrc/internet-crimes/safety_ed.html/>

Denzinger, H., Enchiridion Symbolorum, Definitionum et Declarationum de Rebus Fidei et Morum, $43^{\text {rd }}$ edition, San Francisco: Ignatius Press, 2012. ISBN 978-0-89870-746-5.

Doran, K., The Economics of Pornography, presented at a symposium on "The Social Costs of Pornography," Princeton, New Jersey [December 11-13, 2008], available at: <http://www.winst. org/family_marriage_and_democracy/social_costs_of_pornography/Doran-Economics-Pornography.pdf/>

Family Safe Media, Pornography and Divorce [June 2012], available at: $<$ http://www.divorcewizards.com/Divorce-Statistics-Pornography.html/>

Finn, R., Blessed Are the Pure in Heart: A Pastoral Letter on the Dignity of the Human Person and the Dangers of Pornography, Kansas City-Saint Joseph, MO, 2007.

Giertych, W., O.P., Free Will, Addiction, and Moral Culpability, "Addiction and Compulsive Behaviors: Proceedings from the $17^{\text {th }}$ Workshop for Bishops," Boston: The National Catholic Bioethics Center, 2000. ISBN 0-935372-43-1.

John Paul II, Reconciliatio et Paenitentia, Vatican City State: Libreria Editrice Vaticana, 1984. ISBN 0-85183-608-9.

Loverde, P., Bought with a Price: Every Man's Duty to Protect Himself and His Family from a Pornographic Culture, $2^{\text {nd }}$ edition, Arlington, VA, 2014. 
National Center for Missing and Exploited Children, Reports of Child Exploitation Up, "USA Today Snapshots," [February 17, 2005], available at <http://pqasb.pqarchiver.com/USAToday/ doc/408935815.html>

Pinckaers, S., O.P., Morality: The Catholic View, trans. by Michael Sherwin, O.P., South Bend, IN: Saint Augustine's Press, 2001. ISBN 1-890318-56-6.

Pius XI, Casti Connubii, “Acta Apostolicae Sedis” 22 (1930).

Pontifical Council for the Family, Vademecum for Confessors concerning Some Aspects of the Morality of Conjugal Life, Vatican City State: Libreria Editrice Vaticana, 1997. ISBN 8-82092-342-4.

Second Vatican Council, Gaudium et Spes, in Austin Flannery, ed., Vatican Council II: The Conciliar and Post-Conciliar Documents, Northport, New York: Costello Publishing Company, Inc., 1975. ISBN 0-8420-2079-9.

Stockman, B. J., 7 Negative Effects of Porn [November 2011], available at: <http://theresurgence. com/2011/11/19/7-negative-effects-of-porn/>

United Families International, 14 Shocking Pornography Statistics, [June 2010], available at: <http:// unitedfamiliesinternational.wordpress.com/2010/06/02/14-shocking-pornography-statistics/>

Wojtyla, K., Love and Responsibility, trans. by H. T. Willetts, New York: Farrar, Straus and Giroux, Inc., 1981. ISBN 0-89870-445-6.

Rev. Paul F. deLadurantaye - S.T.L., S.T.D. (Moral Theology), Pontifical John Paul II Institute for Studies on Marriage and the Family, Washington, D.C. Priest of the Diocese of Arlington; Assistant Professor, Notre Dame Graduate School of Christendom College, Alexandria, Virginia. 